\title{
SELECTION AND BIOTECHNOLOGY IN MILK COLLECTION IN UKRAINE AND THE WORLD
}

\section{Pryshed'ko Vladimir ${ }^{1}$}

DOI: https://doi.org/10.30525/978-9934-571-89-3_108

The result of the work of breeding livestock breeders in Ukraine is a number of wonderful breeds and types of farm animals that can be lost. The problem is that the methods for assessing their breeding qualities are not consistent with the assessment system adopted in a number of countries that occupy leading positions in the production of certain types of products. In connection with the situation that has developed in recent years, Ukraine has pumped off the shaft of various genetic products: livestock, embryos, sperm production. Instead of using the achievements of world genetics and breeding to improve certain economic and useful features of local livestock, the process of absorption of domestic breeds and types is very high. It is fully related to cattle breeding - one of the main branches of animal husbandry [1, p. 4; 2, p. 126; 7, p. 324].

In order to prove its ability in the markets of livestock products, including its tribal component, it is necessary, as a last resort, to be equal in technical and technological sense, as well as to have a system of assessment that is understandable for specialists from other countries.

In order to increase the genetic level of cattle, a reliable assessment of the breeding and productive qualities of pedigree boars and breeding stock, as well as a high degree of inheritance of the most important economic and useful features that are the purpose of breeding is necessary. In addition, a small interval between generations is required [5, p. $23 ; 8$, p. 434; 9, p. 877]. The current system for assessing the breeding and productive qualities of dairy and dairy cattle in Ukraine is clearly obsolete.

In view of the above, Ukraine needs to develop a model that can explain the impact on the implementation of the genetic potential of the animal's environment and all its individual family ties. Use to estimate the breeding value of bulls-breeders of the BLAP method (best unbiased prognosis of tribal value) allows for objective comparison. Having a high degree of reliability in the transfer of desirable economic benefits from proband to the descendants, the BLAP method is not devoid of significant disadvantages, which in the first place should include the length of the evaluation process and a significant decline in tribal values in the next generation of daughters born from a younger generation of cows.

The process of evaluating and attributing the tribal status to a pedigree selected for pedigree indicators takes a time span of at least five years. All this time, artificial insemination stations are forced to spend a considerable amount of money on the maintenance of animals, and in the case of obtaining negative results of the productivity of daughters compared with their peers from other bulls to eliminate

\footnotetext{
${ }^{1}$ Dniprovsk State Agrarian-Economic University, Ukraine
} 
them from the herd. Costs are the cost of sperm production and reduce the competitiveness of organizations. During this time, two generations of cows grow, and the probability of transfer of economic benefits to the maternal line from the estimated quality of offspring of the bull-bearer when using it in the next genetic generation is reduced by 20 percent or more. The acceleration of the rate of breeding progress led to the use in livestock genomic selection [3, p. 86; 4, p. 25].

Genomic breeding is a breeding method based on the study of the DNA sequence of animals. It differs significantly from previous attempts to use genetic information to improve breeds. Genomic selection makes it possible to study a large number of DNA markers simultaneously (over 60,000). In the presence of evenly distributed genetic markers in one animal it is possible to estimate its breeding value, based on the relationship between its genotype and the most important economic features: milk yield, milk quality, duration of economic use, reproductive abilities, interior and exterior indicators and other features. This allows the most accurate calculation of the breeding value of the animal through the breeding value index, reducing the time and cost of selecting the best animals for their use in breeding programs. With an accuracy of 75 percent, thanks to the use of the genomic-index method for assessing breeding bulls-breeders, the efficiency of breeding increases at times. Already at the time of birth, his genetic predisposition to the transfer of the desired economic properties to the age, that is, before the beginning of the production use of the bull, becomes known, and after evaluation of the health, growth and development of the bull may be allowed to be widely used in breeding programs. Consequently, genomic selection, as compared with the assessment of the quality of offspring, is as reliable and faster as it provides a multiple reduction of the interval between generations of animals. Genomic selection is much cheaper, there is no need to wait 5 years until the bull is in the evaluation. The obtained results of genomic testing do not change throughout the life of proband [6, p. 5; 10, p. 308].

The method of genotyping is related to the method of estimation of bucks in the quality of offspring. In order to carry out genomic evaluation it is necessary to allocate several stages: the stage of accumulation of information about the genotype of the population which includes the control of cow productivity and evaluation of bulls-progeny by posterity, the identification of markers associated with specific economic characteristics, selection of candidates for genotyping and selection of the best bulls for use in breeding. Today, a robust genomic assessment is available to artificial insemination stations in the countries of North and South America, Europe, Asia, South Africa and Australia. For example, in France alone, 9727 bulls and 17,770 cows and heifers of all breeds were examined for the genotype in 2011, and in 2012, 71114 heads of Holstein breed were subjected to genotyping [6, p. 5; 9, p. 877; 10, p. 309].

It should be noted that the selection of cows was carried out according to pedigree and phenotype. Genotyping markers are an additional reliable way of evaluating decision-making on the use of pedigrees. This is evidenced by world experience. The reliability of the transfer of the economic and useful qualities of bulls estimated at the quality of offspring is: $0.75-0.80$, in young genotypic bulls $-0.65-0.7$, and when 
evaluated only by pedigree -0.3 . Bulls, selected by genome and then tested on the quality of offspring, show equivalent results of the assessment of the productivity and other economic characteristics of the daughters.

The Food and Agricultural Organization (FAO) Global Information System for Animal Genealogy contains information on 7616 breeds of livestock. Among them, about $20 \%$ are classified as those at risk of disappearance. During the last few years, 62 breeds have died out, almost one month per one species breeds. These statistics represent only a partial picture of genetic destruction. For 36\% of breeds there is no necessary data on the assessment of their condition. Among a number of the most productive breeds of cattle, the genetic diversity within the breed is undermined by the use for the reproduction of only a few of the most widespread producers. At the same time, the state of livestock is critical for sustainable development of the state, solving global problems of hunger, the development of domestic and new markets, reducing environmental problems, that is, in general, is critical to the global development of all mankind [5, p. 23].

The task of preserving genetic resources and accelerating breeding require a special approach to control their gene pools [8, p. 4359; p. 877]. To this end, different generations of molecular-genetic markers of polymorphism of separate DNA regions have long been used. With their help solved research tasks such as reconstruction of history and genealogy of breeds, their distribution, elucidation of the specifics of their gene pool; development of genetically grounded programs for the sustainable use of local breeds and their conservation; mapping of the main genes of quantitative traits for genomic selection. These markers were also used to solve such application problems, as exception of errors of origin, development of methods for forecasting the quantity and quality of final products, resistance to the conditions of retention and to infectious agents, control of hereditary diseases and pathogen infections.

\section{References:}

1. Bashhenko, M. I., \& Ruban, S. Ju. (2011). Suchasni metody selekciji molochnoji khudoby. Rozvedennja i ghenetyka tvaryn, (45), 3-7.

2. Boichard, D., Fritz, S., Rossignol, M. N., Guillaume, F., Colleau, J. J., \& Druet, T. (2006). Implementation of marker-assisted selection: practical lessons from dairy cattle. Proc. 8th World Congr. Genet. Appl. Livest. Prod., Commun, 22-31.

3. Glazko, V. I. (2011). Genomnaya selektsiya krupnogo rogatogo skota: issledovatel'skie i prikladnye zadachi. Izvestiya Timiryazevskoy sel'skokhozyaystvennoy akademii, (5).

4. Goddard, M. E., \& Hayes, B. J. (2007). Genomic selection. Journal of Animal breeding and Genetics, 124(6), 323-330.

5. Hayes, B. J., Bowman, P. J., Chamberlain, A. J., \& Goddard, M. E. (2009). Invited review: Genomic selection in dairy cattle: Progress and challenges. Journal of dairy science, 92(2), 433-443.

6. Hayes, B., \& Goddard, M. (2010). Genome-wide association and genomic selection in animal breeding. Genome, 53(11), 876-883.

7. Krughljak, O. V. (2013). Ghospodarsjko-ekonomichni peredumovy zaprovadzhennja ghenomnoji ocinky tvaryn u molochnomu skotarstvi. Ekonomika APK, (9), 85-91.

8. Ruban, S. Ju., \& Kostenko, O. I. (2010). Ocinka efektyvnosti zastosuvannja tradycijnoji ta ghenomnoji skhem selekciji v molochnomu skotarstvi. Redakcijna koleghija, 135.

9. Schefers, J. M., \& Weigel, K. A. (2012). Genomic selection in dairy cattle: Integration of DNA testing into breeding programs. Animal Frontiers, 2(1), 4-9. 
10. Verbyla, K. L., Hayes, B. J., Bowman, P. J., \& Goddard, M. E. (2009). Accuracy of genomic selection using stochastic search variable selection in Australian Holstein Friesian dairy cattle. Genetics research, 91(5), 307-311. 